\title{
Carbohydrate Reserves in the Newborn Infant
}

\author{
HEATHER J. SHELLEY,* M.A., D.PHIL.
}

Foetal animals of many species lay down glycogen in the liver during the latter part of gestation and those of some species also accumulate large amounts in the skeletal muscles (Shelley, $1960,1961)$. In both tissues the concentration at term is usually higher than in the adult, but it falss to or below the adult level within a few hours of birth even in normal well-fed newborn animals. In most species the foetal heart also contains a high concentration of glycogen at term, which enables it to continue beating in conditions of extreme oxygen lack (Dawes et al., 1959 ; Mott, 1961). Thus these carbohydrate reserves may be of considerable importance in enabling the newborn animal to survive the changes in food and oxygen supply which occur at birth. The present investigation was undertaken to determine to what extent this is also true for man.

\section{Material and Methods}

Tissue samples were collected from 14 fresh stillbirths (where the foetal heart had been heard during or shortly before delivery) and 116 infants who had died within two weeks of birth at three large hospitals. Whenever possible the samples were taken within 10 to 20 minutes of death, but more often it was necessary to wait for necropsy (usually one to three days later), the infant having been refrigerated within 20 to 30 minutes of death. It was hoped that the measurement of total carbohydrate rather than glycogen would minimize the effects of this delay; in six cases where samples were taken both shortly after death and at necropsy there was little difference in the carbohydrate content of the two sets of samples (Table I). Biopsy samples of skeletal muscle were taken from 10 other infants during surgical operations for congenital malformations-for example, meningomyelocele, duodenal atresia, imperforate anus.

\begin{tabular}{|c|c|c|c|c|}
\hline \multirow{2}{*}{$\begin{array}{l}\text { Sampling Time } \\
\text { Hours } \\
\text { after Death }\end{array}$} & \multicolumn{4}{|c|}{ Total Carbohydrate (mg./g. Wet Wt.) } \\
\hline & Heart* & Liver & Diaphragm & Muscle† \\
\hline $\begin{array}{c}0.5 \\
(0.2-0.8)\end{array}$ & $\begin{array}{c}13 \cdot 9 \\
(0 \cdot 6-39 \cdot 3)\end{array}$ & $\begin{array}{c}10 \cdot 1 \\
(2 \cdot 2-25 \cdot 8)\end{array}$ & $\begin{array}{c}7 \cdot 7 \\
(0 \cdot 0-13 \cdot 4)\end{array}$ & $\begin{array}{c}8 \cdot 2 \\
(7 \cdot 2-9 \cdot 2)\end{array}$ \\
\hline $\begin{array}{c}41 \cdot 5 \\
(18-50)\end{array}$ & $\begin{array}{c}9 \cdot 5 \\
(1 \cdot 4-24 \cdot 8)\end{array}$ & $\begin{array}{c}9 \cdot 2 \\
(1 \cdot 0-27 \cdot 3)\end{array}$ & $\begin{array}{c}8 \cdot 3 \\
(0.0-18 \cdot 5)\end{array}$ & $\begin{array}{c}6 \cdot 1 \\
(2 \cdot 0-9 \cdot 6)\end{array}$ \\
\hline
\end{tabular}

Each sample (usually 100-200 mg. of tissue) was placed immediately in $1-2 \mathrm{ml}$. of $5 \% \mathrm{w} / \mathrm{v}$ trichloroacetic acid solution containing $0.15 \% \mathrm{w} / \mathrm{v}$ silver sulphate in a brown glass bottle and was then stored in the refrigerator. The samples+ deproteinizing reagent were usually analysed within a few days, by the method of Kemp and Kits van Heijningen (1954), but sometimes there was a delay of several weeks. This did not seem to affect the results.

The maturity of the infants was estimated from the date of the last menstrual period supported by clinical observations and necropsy findings.

\section{Results}

Eighteen infants of 28-33 weeks' maturity (including five stillbirths) and 11 infants of more than 37 weeks' maturity (including eight stillbirths) died within four hours of birth. Most of these deaths were associated with some degree of hypoxia, occurring either in utero or after birth (as in two cases with primary atelectasis, two with pulmonary hypoplasia, two with hyaline membrane disease, two with diaphragmatic hernias, and one case with erythroblastosis foetalis). Two infants died suddenly as the result of obstetric accidents : one, a grossly hydropic infant of 32 weeks' maturity, suffered a cervical dislocation during delivery; the other, a normal infant of 40 weeks' maturity, was delivered precipitately and died immediately, after a tentorial tear.

Table II summarizes the results obtained from these two groups of infants. Whereas the carbohydrate concentration in the heart (ventricle) was similar in both groups, that in the liver and leg muscles was higher in the infants near term than in the premature infants. The two infants who died suddenly had exceptionally high cardiac carbohydrate concentrations

TABLE II.-Heart, Liver, and Skeletal-muscle Carbohydrate in Premature and Mature Infants Dying Within Four Hours of Birth (Including Stillbirths). Means \pm S.E. with Maximum Values in Parentheses

\begin{tabular}{|c|c|c|c|c|}
\hline \multirow{2}{*}{$\begin{array}{l}\text { Maturity } \\
\text { (Weeks) }\end{array}$} & \multirow{2}{*}{$\begin{array}{l}\text { No. of } \\
\text { Infants }\end{array}$} & \multicolumn{3}{|c|}{ Total Carbohydrate (mg./g. Wet Wt.) } \\
\hline & & Heart* & Liver & Skeletal Musclet \\
\hline $\begin{array}{l}31 \cdot 3 \pm 0 \cdot 3 \\
39 \cdot 5 \pm 0.6\end{array}$ & $\begin{array}{l}18 \\
11\end{array}$ & $\begin{array}{r}7 \cdot 6 \pm 2 \cdot 3(39 \cdot 3) \\
10 \cdot 1 \pm 4 \cdot 4(47 \cdot 0)\end{array}$ & $\begin{array}{r}9 \cdot 8 \pm 1 \cdot 5(27 \cdot 8) \\
39 \cdot 2 \pm 5 \cdot 1(71 \cdot 8)\end{array}$ & $\begin{array}{l}16 \cdot 3 \pm 1 \cdot 1(21 \cdot 0) \\
26 \cdot 7 \pm 3 \cdot 2(43 \cdot 4)\end{array}$ \\
\hline
\end{tabular}

- Apex of ventricles. † Anterior tibial, semitendinosus, or gastrocnemius muscle.

(Table II, in parentheses), and in both groups the liver carbohydrate concentration tended to be highest in infants where the period of hypoxia was thought to have been short. The skeletalmuscle carbohydrate concentration did not seem to be affected by acute hypoxia. In each group the concentration in the back muscles (latissimus dorsi or paravertebral) was similar to that in the leg muscles (Table II), but that in the rectus abdominis and anterior intercostal muscles was usually rather lower, and that in the diaphragm was lowest of all (up to $13.5 \mathrm{mg} . / \mathrm{g}$. in the premature group and $21.5 \mathrm{mg} . / \mathrm{g}$. nearer term).

The carbohydrate levels in the older infants varied not only with their maturity but also with their age and clinical history. Table III compares the levels in infants dying at 1-12, 13-25, and $26-54$ hours after birth. Section $A$ gives the mean values for infants with near-normal or depressed respiratory activity and section $B$ those for infants with persistently laboured respiration. Both groups contained both premature and mature infants. Section A included 10 deaths attributable to extreme prematurity, three due to birth asphyxia, two to depressed respiratory activity and secondary atelectasis, one to primary atelectasis, two to pulmonary hypoplasia, one to a diaphragmatic hernia, one to a congenital heart defect, one to cardiac failure of unknown origin, one to erythroblastosis foetalis, and one undiagnosed death. Section B included 27 deaths from classical hyaline membrane disease (respiratory distress syndrome) and 10 infants who had been in severe respiratory distress for other reasons-for example, intra-alveolar pulmonary haemorrhage, inhaled amniotic debris, $\mathrm{O}_{2}$ resorption atelectasis.

In the infants with minimal respiratory distress (Table III A), the mean cardiac carbohydrate concentration was similar to that in Table II and did not seem to change during the first two

\footnotetext{
* Nuffield Institute for Medical Research, University of Oxford.
} 
days after birth, but the liver carbohydrate fell rapidly during the first few hours and then remained relatively constant at a mean value of $11 \mathrm{mg} . / \mathrm{g}$. The diaphragm carbohydrate also fell during the first few hours and was then unchanged, but the level in the leg muscles fell more slowly. A slow rate of fall similar to that in the leg muscles was observed in biopsy samples from the paravertebral or latissimus dorsi muscles of three infants, but the concentrations in the rectus abdominis muscles (both necropsy and biopsy material) approximated more closely to those in the diaphragm. A similar range of values to those on the second day was found in seven infants who died at 4-12 days of age as the result of kernicterus (1), congenital malformations, pneumonia, or acute cerebral haemorrhage, but two infants with chronic cerebral lesions (subdural or intraventricular haemorrhages which were thought to have occurred at birth) and depressed respiration still had foetal carbohydrate levels of $27-28 \mathrm{mg}$. $/ \mathrm{g}$. in the diaphragm and $35-39 \mathrm{mg} . / \mathrm{g}$. in the leg muscles 6 to 12 days after birth.

The concentrations in the infants with severely laboured respiration (Table III B) were all lower than the corresponding levels in Table III A ; indeed, they were often so low that they could not be measured accurately and the values in Table III B are probably too high (Searle and Woodhouse, 1958). Regard-

\begin{tabular}{|c|c|c|c|c|c|c|c|}
\hline & \multirow{2}{*}{$\begin{array}{l}\text { No. of } \\
\text { Infants }\end{array}$} & \multirow{2}{*}{$\begin{array}{c}\text { Mean } \\
\text { Maturity } \\
\text { (Weeks) }\end{array}$} & \multirow{2}{*}{$\begin{array}{l}\text { Mean } \\
\text { Age from } \\
\text { Birth } \\
\text { (Hours) }\end{array}$} & \multicolumn{4}{|c|}{ Total Carbohydrate (mg./g. Wet Wt.) } \\
\hline & & & & Heart* & Liver & Diaphragm & $\begin{array}{c}\text { Leg } \\
\text { Muscles† }\end{array}$ \\
\hline & $\begin{array}{r}15 \\
4 \\
4\end{array}$ & $\begin{array}{l}30 \cdot 0 \\
32 \cdot 3 \\
33 \cdot 6\end{array}$ & $\begin{array}{r}2 \cdot 1 \\
19 \cdot 3 \\
41 \cdot 8\end{array}$ & $\begin{array}{l}7 \cdot 8 \pm 2 \cdot 0 \\
4 \cdot 4 \pm 2 \cdot 3 \\
9 \cdot 4 \pm 5 \cdot 3\end{array}$ & $\begin{array}{l}19 \cdot 5 \pm 5 \cdot 1 \\
10 \cdot 8 \pm 8 \cdot 7 \\
11 \cdot 1 \pm 5 \cdot 1\end{array}$ & $\begin{array}{l}9 \cdot 6 \pm 1 \cdot 0 \\
5.5 \pm 0.9 \\
7 \cdot 6 \pm 2 \cdot 3\end{array}$ & $\begin{array}{l}21.4 \pm 2.6 \\
13.8 \pm 3.2 \\
12.0 \pm 4.9\end{array}$ \\
\hline & $\begin{array}{r}18 \\
8 \\
11\end{array}$ & $\begin{array}{l}32 \cdot 1 \\
34 \cdot 8 \\
32 \cdot 3\end{array}$ & $\begin{array}{r}6 \cdot 4 \\
18 \cdot 3 \\
39 \cdot 5\end{array}$ & $\begin{array}{l}<2.5 \pm 0.5 \\
<3.1 \pm 0.7 \\
<3.1 \pm 0.7\end{array}$ & $\begin{array}{l}<4 \cdot 6 \pm 1 \cdot 0 \\
<2 \cdot 7 \pm 0 \cdot 5 \\
<2 \cdot 2 \pm 0 \cdot 4\end{array}$ & $\begin{array}{l}<2 \cdot 0 \pm 0.2 \\
<1 \cdot 7 \pm 0.1 \\
<1 \cdot 0 \pm 0.3\end{array}$ & $\begin{array}{r}14.1 \pm 1.1 \\
9.6 \pm 1.7 \\
<3.4 \pm 0.8\end{array}$ \\
\hline
\end{tabular}

- Apex of ventricles. † Anterior tibial, semitendinosus, or gastrocnemius muscle.

less of age after birth or maturity, these infants had almost completely exhausted the carbohydrate in the diaphragm and had usually exhausted that in the heart and liver. In infants dying on the first day the leg-muscle carbohydrate was only slightly lower than the corresponding values in Table III A, but by the second day this, too, was often exhausted, particularly in the more premature infants. The level in the rectus abdominis muscles approximated more closely to that in the diaphragm, but those in the anterior intercostal and latissimus dorsi muscles were usually a little higher. The diaphragm carbohydrate was also low (1.3-4.8 mg./g.) in six infants with respiratory distress due to other conditions (three with congenital heart defects, three with erythroblastosis foetalis); the levels in the other tissues were variable.

The infants in Table III B were all thought to have died from their pulmonary disorders, although some had also sustained a cerebral haemorrhage. However, six other infants whose respiratory condition was improving died unexpectedly as the result of inhaled vomit (1) or massive pulmonary or intraventricular haemorrhages. Although their cardiac and liver carbohydrate was usually low, the levels in the diaphragm and general musculature were higher than those in Table III B, similar to those in III A.

Very low carbohydrate levels in all tissues (often $<1 \mathrm{mg} . / \mathrm{g}$.) were also observed in several infants without respiratory distress. They included two extremely premature infants (23-25 weeks maturity) who survived for more than 24 hours, three dysmature infants weighing 2-5 lb. (910-2,270 g.) at 37-40 weeks maturity who died at 10,13 , and 96 hours, and three infants of 34-42 weeks' maturity whose placentas had been described as unhealthy, infarcted, or meconium-stained who died at 30-46 hours. Unexpectedly low values were found in four other infants who were " rather small for dates" and in three weigh- ing more than $10 \mathrm{lb}$. (4,535 g.) at term ; each of these groups included one stillbirth-the mothers of the large babies were not diabetic. Two infants who did have diabetic mothers had tissue-carbohydrate levels in keeping with their age, maturity, and clinical history.

\section{Discussion}

\section{Changes During Gestation}

The data shown in Table II suggest that, as in other species (Shelley, 1960, 1961), the carbohydrate concentration in the human foetal heart is higher than in the adult and that the concentration in the liver and skeletal muscles rises during the last third of pregnancy. Since acute asphyxia produces a rapid fall in cardiac and liver carbohydrate in foetal and newborn animals (Dawes et al., 1959 ; Stafford and Weatherall, 1960), it is likely that the levels in the normal unasphyxiated human foetus are nearer the maximum values in Table II than the means, though since skeletal-muscle carbohydrate is unaffected by acute asphyxia the mean values for this tissue may approximate to normal.

Thus the very high cardiac carbohydrate concentration in the two unasphyxiated stillbirths was similar to that in foetal animals early in gestation (Shelley, 1961) and to the cardiac glycogen concentration in fresh human material at 9-21 weeks' maturity (Villee, 1954) and in some post-mortem material (Wittels, 1963). Whereas Wittels ignored the depleting effect of asphyxia and concluded that the cardiac glycogen concentration fell during the latter part of gestation, the present work suggests that it may be maintained at about 10 times the adul concentration right up to term. If, as in other species, the ability to survive anoxia is related to the cardiac glycogen concentration (Dawes et al., 1959 ; Mott, 1961), this may partly explain the exceptional tolerance of the newborn infant to oxygen lack (Bullough, 1958).

Data from fresh human material (Villee, 1954) suggest that liver glycogen begins to accumulate at about 10 weeks' maturity and has reached $20-40 \mathrm{mg}$./g. by $15-20$ weeks. Much lower concentrations were found in post-mortem material (Szendi, 1936), but there was a steady increase right up to term. The present work suggests that the liver glycogen rises from 30 to $80 \mathrm{mg} . \mathrm{g}$. or more during the last third of pregnancythus the level at term is probably about twice the usual adult concentration. The skeletal-muscle carbohydrate also doubled during the latter part of gestation, reaching levels three to five times the adult concentration at term. Similar changes were observed in foetal lambs and rhesus monkeys (Shelley, 1960, 1961).

\section{Changes After Birth}

In newborn animals reared under normal conditions the liver carbohydrate usually falls to about $10 \mathrm{mg}$./g. within two to three hours of birth, remains at this low level for several davs, and then rises gradually to adult levels (Shelley, 1961). The skeletal-muscle carbohydrate falls more slowly but usually reaches the adult level within one to three days of birth and is unchanged thereafter. The cardiac carbohydrate falls much more slowly and varies from species to species. The carbohydrate levels in the infants with minimal or no respiratory distress (Table III A, older infants, and biopsy samples) suggest that similar changes occur in man.

But in many infants the levels fell still lower. Of 101 infants who died within 1 to 60 hours of birth, 74 had less than $3 \mathrm{mg} . / \mathrm{g}$. in at least one tissue-that is, the tissue glycogen was probably exhausted. In 21 infants one tissue only was affected (usually heart or diaphragm in infants dying within 12 hours of birth), 24 had two tissues affected (usually heart and liver or heart and diaphragm), 20 had three tissues affected (usually 
heart, liver, and diaphragm), and 9 had low carbohydrate levels in all tissues (usually infants who survived for more than 24 hours). While it could be argued that some of the low values were due to post-mortem changes, this is unlikely to be true of the liver, and lack of liver glycogen could well explain the high incidence of hypoglycaemia in newborn infants; blood samples taken within a few minutes of death from about half the infants in the present series often had a glucose content of less than $4 \mathrm{mg}$. $/ 100 \mathrm{ml}$. Similar blood glucose and liver carbohydrate levels have been observed in lambs and monkeys which had been asphyxiated at birth and then resuscitated (Dawes et al., 1963a), and low cardiac carbohydrate concentrations are found in acute asphyxia (Dawes et al., 1959, 1960, 1963b; Stafford and Weatherall, 1960).

It is reasonable to suppose that skeletal-muscle carbohydrate could be completely depleted in vigorous muscular exercise and that this would explain the exceptionally low values in the diaphragm (Table III B) and rectus abdominis muscles of infants dying in respiratory distress; the diaphragm glycogen fell more rapidly in piglets with distressed respiration than in normal controls (Glauser et al., 1962) and was completely depleted in a premature monkey with severe respiratory distress (Dawes et al., 1963a). Low carbohydrate levels in leg muscle were found only in infants of less than 36 weeks' maturity, where the initial concentration was probably below that at term (Table II), and in mature infants where there was reason to expect unusually low levels at birth, possibly due to placental insufficiency (dysmature infants, infants with grossly unhealthy placentas) or large size (cf. monkey No. 110, Dawes et al., 1960).

Thus it is tempting to suggest that in some cases hypoglycaemia and/or lack of glycogen in a vital organ (heart or diaphragm) may have been the ultimate cause of death. Whereas fat is undoubtedly an important source of energy in normal newborn infants, carbohydrate is probably more important when oxygen is short. But in these circumstances the $\mathrm{pH}$ of the blood and tissues is likely to be low and the intravenous administration of glucose alone may be ineffective or may lead to increased formation of lactic acid and a further fall in pH (Dawes et al., 1963b). Therefore it is advisable not only to administer glucose but also to monitor and correct the arterial $p H$ in infants where the pulmonary ventilation is impaired.

\section{Summary}

Tissue samples from 14 fresh stillbirths and 116 infants who had died within two weeks of birth, and muscle-biopsy samples from 10 other infants, have been analysed for their total carbohydrate content.

The results obtained from infants dying within four hours of birth suggested that during the last third of pregnancy the foetal liver carbohydrate rises to about twice, and the skeletalmuscle carbohydrate to three to five times, the adult level. The carbohydrate concentration in the heart probably remains at about 10 times the adult level throughout this period.

The carbohydrate levels in the older infants varied with age, maturity, and clinical history. In infants with minimal respiratory distress the liver carbohydrate fell to about $10 \%$ of the level at term within a few hours of birth and the skeletal-muscle carbohydrate fell to adult levels ; there was no abrupt change in cardiac carbohydrate. Much lower values were observed in infants with persistent respiratory distress and the diaphragm carbohydrate was usually exhausted.

Unexpectedly low carbohydrate levels were also observed in babies who were "small for dates" and in three exceptionally large babies.

The results are discussed in relation to other species and to their possible significance.

I am greatly indebted to Dr. Victoria Smallpeice, Dr. Pamela Davies, and Dr. W. A. Aherne, of the Radcliffe Infirmary, Oxford; Dr. G. A. Neligan, of the Department of Child Health, University of Newcastle upon Tyne; and Dr. J. P. M. Tizard and Dr. J. A. Davis, of the Department of Child Health, Hammersmith Hospital, London, for their generous co-operation in this work, both in supplying the samples and in discussing the case histories. I also wish to thank Mrs. Margaret Young for her help in analysing the samples.

\section{REFERENCES}

Bullough, J. (1958). Lancet, 1, 999.

Dawes, G. S., Jacobson, H. N., Mott, J. C., and Shelley, H. J. (1960). f. Physiol. (Lond.), 152, 271.

$--\frac{1}{\text { Tot }}$ and Stafford, A. (1963a). Ibid., 169, 167.

- Mott, J. C., and Shelley, H. J. (1959). Ibid., 146, 516.

-1 and Stafford, A. (1963b). Ibid., 168, 43.

Glauser, E. M., McCance, R. A., and Widdowson, E. M. (1962). Ibid., 161, 313.

Kemp, A., and Kits van Heijningen, A. J. M. (1954). Biochem. F., 56, 646.

Mott, J. C. (1961). Brit. med. Bull., 17, 144.

Searle, C. E., and Woodhouse, D. L. (1958). Biochem. F., 69, 18P.

Shelley, H. J. (1960). F. Physiol. (Lond.), 153, 527.

- (1961). Brit. med. Bull., 17, 137.

Stafford, A., and Weatherall, J. A. C. (1960). F. Physiol. (Lond.), 153, 457.

Szendi, B. (1936). Arch. Gynäk., 162, 27.

Villee, C. A. (1954). Cold Spr. Harb. Symp. quant. Biol., 19, 186.

Wittels, B. (1963). Arch. Path., 75, 127.

JAMES BUCHANAN, M.B., M.R.C.P.ED., M.R.C.P.GLASG.; IAN MURRAY, M.D., F.R.C.P.ED., F.R.C.P.GLASG.

Brit. med. F., 1964, 1, 275-278

Ten years have elapsed since the introduction of insulin zinc suspension ("lente" insulin) to this country. The earlier reports on its use (Lawrence and Oakley, 1953 ; Murray and Wilson, 1953 ; Nabarro and Stowers, 1953 ; Venning, 1954) led to the conclusion that it would effect satisfactory control in more than $80 \%$ of patients requiring insulin. Nevertheless it

* From the Department of Metabolic Diseases, Victoria Infirmary, Glasgow.

† Present address : Royal Hospital for Sick Children, Glasgow. was generally agreed that I.Z.S. proved inadequate in some cases. In a later review (Lancaster and Murray, 1958) it was found that although good results were obtained in $82.5 \%$ of 135 new patients, in only $64.7 \%$ of 201 patients who had previously received some other form of insulin did it prove satisfactory. More recently, Oakley (1961) reported that while good control was obtained in over $80 \%$ of previously untreated cases late results were poor in diabetics requiring high insulin dosage, particularly in young patients. 